\title{
Arthritis as a Presenting Feature of IBD-A Study from Eastern India
}

\author{
Bhaswati C Acharyya ${ }^{1 *}$, Mandira roy ${ }^{2}$, Souvik Guha ${ }^{2}$ and Priyankar Pal ${ }^{2}$ \\ ${ }^{1}$ Department of Paediatric Gastroenterology, Institute of Child Health, India \\ ${ }^{2}$ Department of Paediatrics, Institute of Child Health, India
}

Submission: May 01, 2018; Published: May 16, 2018

*Corresponding author: Bhaswati C Acharyya, Department of Paediatric Gastroenterology, Institute of Child Health, Kolkata, India, Email: bukuli2@hotmail.com

Abbreviation: IBD: Inflammatory Bowel Disease; CD: Crohn's Disease; IBDU: Inflammatory Bowel Disease Unclassified; LNH: Lymphoid Nodular Hyperplasia

\section{Introduction}

Arthropathy is one of the extraintestinal manifestations of IBD. Arthritis associated with Inflammatory Bowel disease (IBD) is a subset of arthritis in the Enteropathic arthritis family. The aim of the present study is to find out the patients who presented with arthropathy as presenting feature preceeding the GI symptoms and study their clinical profile.

\section{Materials and Methods}

Case records of patients of IBD diagnosed between May 2010 and May 2017 in two tertiary centres of Kolkata were analysed to find out the patients presenting with Arthropathies. Case records of those patients were reviewed to find out the clinical profile of those children. Clinical data was analysed under the headings of 1) Age at presentation 2) Interval of onset of arthropathy and

Table 1: Clinical profile of IBD patients presenting with Arthropathy. diagnosis of IBD, 3) Type of IBD, 4) Type of Arthropathy 5) Other features of IBD, 6) Endoscopic features of IBD 7) Microscopy of IBD and 8) treatment outcome.

\section{Result}

Total case records of 55 patients with IBD were analysed. 3 patients were found to have arthropathy as presenting feature. Clinical profiles of these patients were as follows: (Table 1) so prevalence of arthropathy as presenting features in this specified IBD populationwas $5.45 \%$. It was associated with CD or IBD U. All arthritis preceded abdominal symptoms. All arthropathic patients had colitis (patchy or pancolitis). Only one had seropositivity of HLA B27 and rest 2 were seronegative. Average period to diagnosis from onset of arthropathy was 9.3 months. In all cases Fecal Calprotectin was markedly raised.

\begin{tabular}{|c|c|c|c|c|c|c|c|c|}
\hline Patient & Age & $\begin{array}{l}\text { Interval of } \\
\text { Arthropathy } \\
\text { and } \\
\text { Diagnosis of } \\
\text { IBD }\end{array}$ & IBD & $\begin{array}{c}\text { Type of } \\
\text { Arthropathy }\end{array}$ & $\begin{array}{c}\text { Other Features } \\
\text { of IBD }\end{array}$ & Endoscopy & Microscopy & $\begin{array}{l}\text { Treatment } \\
\text { Outcome }\end{array}$ \\
\hline Case 1 & $13 y r s$ & 1 year & $\mathrm{CD}$ & $\begin{array}{l}\text { Low backache. } \\
\text { HLAB27 positive } \\
\text { sacroilitis }\end{array}$ & $\begin{array}{c}\text { Diarrhea, } \\
\text { Weight loss } \\
\text { 10kg Intestinal } \\
\text { perforation } \\
\text { Fecal } \\
\text { Calprotectin } \\
1218\end{array}$ & $\begin{array}{l}\text { Multiple } \\
\text { patchy deep } \\
\text { penetrating } \\
\text { ulcers in } \\
\text { colon with } \\
\text { narrowing of } \\
\text { Caecum }\end{array}$ & $\begin{array}{l}\text { Extensive } \\
\text { fibrosis in } \\
\text { caecum } \\
\text { along with } \\
\text { chronic active } \\
\text { inflammation } \\
\text { in colon }\end{array}$ & $\begin{array}{l}3 \text { year follow up } \\
\text { On Steroid } \\
\text { induction and } \\
\text { Azathioprine } \\
\text { maintenance } \\
\text { No joint pain } \\
\text { after } 6 \text { months } \\
\text { Microscopic } \\
\text { remission } \\
\text { maintained } \\
\text { so far }\end{array}$ \\
\hline
\end{tabular}




\begin{tabular}{|c|c|c|c|c|c|c|c|c|}
\hline Case 2 & $7 y r s$ & 7 months & CD & $\begin{array}{l}\text { Bilateral knee } \\
\text { joint pain with } \\
\text { swelling } \\
\text { Seronegative. } \\
\text { MRI synovitis } \\
\text { with effusion }\end{array}$ & $\begin{array}{l}\text { Aphthous } \\
\text { stomatitis along } \\
\text { with arthritis } \\
\text { Later abdominal } \\
\text { pain, bloody } \\
\text { diarrhoea } \\
\text { Weight loss } 5 \mathrm{~kg} \\
\text { Calprotectin } \\
2000\end{array}$ & $\begin{array}{c}\text { Extensive } \\
\text { patchy colonic } \\
\text { ulcerations, } \\
\text { Deep ileal } \\
\text { ulceration } \\
\text { with Duodenal } \\
\text { nodularity } \\
\text { and aphthous } \\
\text { ulcers in } \\
\text { stomach }\end{array}$ & $\begin{array}{l}\text { Chronic active } \\
\text { inflammation } \\
\text { in colon } \\
\text { duodenum, } \\
\text { stomach and } \\
\text { ileum }\end{array}$ & $\begin{array}{c}\text { 2y follow up } \\
\text { doing well on } \\
\text { Azathioprine } \\
\text { Arthritis } \\
\text { subsided after } 4 \\
\text { months }\end{array}$ \\
\hline Case 3 & 3 years & 9 months & IBDU & $\begin{array}{l}\text { Hands and knee } \\
\text { swelling } \\
\text { Seronegative, } \\
\text { Mild joint } \\
\text { effusion no } \\
\text { other feature on } \\
\text { MRI }\end{array}$ & $\begin{array}{l}\text { Blood in stool } \\
\text { thought of anal } \\
\text { fissure } \\
\text { Developed } \\
\text { severe fissure, } \\
\text { Intermittent } \\
\text { fever } \\
\text { Calprotec-tin } \\
1012\end{array}$ & $\begin{array}{l}\text { Extensive } \\
\text { proctocolitis } \\
\text { up to hepatic } \\
\text { flexure, Ileum } \\
\text { LNH,stomach } \\
\text { also showed } \\
\text { ulcers and } \\
\text { erosions from } \\
\text { fundus to } \\
\text { antrum and } \\
\text { aphthous } \\
\text { ulcers in } \\
\text { duodenum }\end{array}$ & $\begin{array}{c}\text { Active } \\
\text { inflammation } \\
\text { with marked } \\
\text { cryptitis, and } \\
\text { crypt abscess } \\
\text { in colon, } \\
\text { Chronic } \\
\text { active } \\
\text { Inflammation } \\
\text { in stomach } \\
\text { and colon }\end{array}$ & $\begin{array}{c}\text { FU so far of } \\
11 \text { months } \\
\text { arthropathy } \\
\text { subsided in } 3 \\
\text { months, stable } \\
\text { on Azathioprine } \\
\text { and Meselamine }\end{array}$ \\
\hline
\end{tabular}

\section{Discussion}

Prevalence of spondylitis and peripheral arthritis is similar in UC and CD [1]. But the extra-intestinal

manifestations tend to be more frequent with colonic involvement [2]. All 3 of our cases had colonic involvement. It is of note that children with arthritis tended to have more severe IBD than those without arthritis [3]. According to some authors, CD may remain subclinical for years or even for life, and therefore the arthritis can be the only clinical expression of the disease [4]. Before onset of GI symptoms all the above 3 cases did not have relief of symptoms and cause of arthritis remained undiagnosed (except the HLAB27 positive case). Except mild relief of pain with supportive therapy they did not have any real remission.

It should be of note that Fecal Calprotectin was markedly raised in all these three patients. Calprotectin is a good noninvasive marker for gut inflammation which is still not very widely available and used tool in eastern side of the Globe. That's why we recommend monitoring of all patients with joint pain in Rheumatology clinic with fecal Calprotectin to detect gut involvement early and to decide endoscopic requirement for avoidance of delay in detecting IBD. Though this is a regular practice in the Western world, is still not a routine in the developing world.

\section{Conclusion}

It was shown that the symptoms and signs of CD in children are often subtle and nonspecific. CD should be considered in the differential diagnosis of children with arthralgia to reduce the latent period to diagnose IBD. Fecal Calprotectin can highlight the presence of bowel inflammation. It can be effectively used as an early marker to suspect IBD and to proceed for endoscopic studies.

\section{References}

1. Mader R, Segol O, Adawi M, Trougoboff P, Nussinson E (2005) Arthritis or vasculitis as presenting symptoms of Crohn's disease. Rheumatol Int 25(6): 401-405.

2. Greenstein AJ, Janowitz HD, Sachar DR (1976) The extraintestinal complications of Crohn's disease and ulcerative colitis: a study of 700 patients. Medicine 55(5): 401-412.

3. Burbige EJ, Huang SS, Bayless TM (1975) Clinical manifestations of Crohn's disease in children and adolescents. Pediatrics 55(8): 866-871.

4. Mielants H, Veys E (1984) Ileal inflammation in B27 positive reactive arthritis. Lancet 1(8371): 288. 


\section{Your next submission with JuniperPublishers will reach you the below assets}

- Quality Editorial service

- Swift Peer Review

- Reprints availability

- E-prints Service

- Manuscript Podcast for convenient understanding

- Global attainment for your research

- Manuscript accessibility in different formats

( Pdf, E-pub, Full Text, audio)

- Unceasing customer service

Track the below URL for one-step submission https://juniperpublishers.com/online-submission.php 